\title{
Indian turmoil over planned US tests of new vaccines
}

New Delhi

A ROUGH passage is predicted for the trials in India of genetically engineered vaccines proposed under the agreement between the United States and the Indian Department of Biotechnology (DBT) signed in July (see Nature 328, 287; 1987). Apart from the ethics of using Indians for trying out new vaccines, questions have been raised about the desirability of giving the United States access to militarily sensitive data on epidemiology and immunity profiles of the population.

DBT insists that there is no basis for concern and that the agreement was signed only after interministerial consultation and cabinet approval. But Dr Pushpa Bhargava, director of the Centre for Cellular and Molecular Biology at Hyderabad, says that "such an important agreement" should not have been signed without consideration by DBT's own scientific advisory committee, of which he is a member.

In a public statement, Bhargava warns against trials with imported genetic vaccine before "we are in a position to design and do every trial and test ourselves". He also complains that the government has done nothing to set up research and production facilities in biotechnology, but is willing to "depend on what we receive from outside".

Sharing Bhargava's views, Dr D. Banerjee, chairman of the Centre of Social Medicine and Community Health of the Jawaharlal Nehru University in New Delhi, describes the agreement as "most disturbing".

In another development, an official of the National Institute of Communicable Diseases (NICD) under the Health Ministry has made it clear that NICD is opposed to open trial of the rabies-vaccinia recombinant virus vaccine for controlling rabies in stray dogs. This is one of the several vaccines the United States had offered for trials.

The controversy has been further sharpened by provisions in the agreement allowing the participation of private US companies in the trials, and US representatives on the environmental riskassessment committee. In addition, India cannot enter into contracts or hire professional services without US approval.

Access to epidemiological data is another issue. The United States planned, as part of the programme, an epidemiology centre to develop a computerized database on "health-profile and demographic information" of well-defined populations. That such information is needed to assess a vaccine's efficacy is not denied, but whether it should be shared with an outside agency is questioned.

According to Bhargava, epidemiological data on immunocompetence "can be of strategic importance". The absence in India of yellow fever, or of a single case of overt AIDS (acquired immune deficiency syndrome), may be due to a peculiar immunocompetence of the Indian population; those knowledgeable about developments in biological warfare resent any collaboration that might enable outsiders to study the immunological "herd structure" that apparently provides a natural barrier against certain infections.

DBT says that the idea of an epidemiology centre has been shelved and that the $\$ 1.2$ million earmarked in the agreement is for epidemiology research and training. Countering allegations that Indians will become guinea-pigs, DBT says that no vaccine will be tried without "prior clearance of the ethics committee of the Indian Council of Medical Research and the Drug Controller of India".

According to DBT, the programme aims chiefly at developing new vaccines against the major diseases of India through joint research with US scientists. DBT also says that the controversy is premature because specific details of the projects have yet to be worked out, and that they will have to be cleared internally before being presented to the US side.

One of the internal bodies, whose clearance is mandatory, is the high-level committee set up in 1975 by the cabinet specifically to screen all foreign-aided research projects from the "security and sensitivity angle". It is headed by the cabinet secretary and includes the scientific adviser to the Defence Ministry, the secretary to the Department of Science and Technology and the other administrative secretaries whose portfolios are affected.

Among other things, the committee must satisfy itself that the project is under Indian control and that there is no military implication. Under the committee's guidelines, "the study should not allow access by foreigners to sensitive information or data", and projects involving communicable diseases, biological and virological studies must be particularly subjected to "searching and critical scrutiny".

Because of the controversy already created by the agreement, the committee is likely to examine DBT's proposals thoroughly before granting clearance. Some say the controversy could have been avoided if the United States had been content with training Indian scientists in vaccine technology, leaving the clinical trials entirely to the Indians.

K.S. Jayaraman

\section{Israelis scrap Lavi}

Tel Aviv

THE Israeli government announced last week that it has decided to scrap the controversial Lavi fighter jet project, causing thousands of Israel Aircraft Industries (IAI) workers to react with fury and threaten to "cut off the state of Israel". But their nationwide protests - blocking runways at Ben-Gurion Airport, setting up roadblocks on major highways and manhandling officials - were spurred less by support for Lavi than by fear that dreams of "lifetime employment" are now gone.

The treasury and defence ministry are now frantically trying to minimize the number of dismissals at IAI and its subcontractors. An estimated 4,000 workers could lose their jobs over the next few years, many of whom may leave Israel if alternative projects are not quickly found. At the beginning of this week, some 15,000 protesters vowed to bring down the government unless a way was found to revive Lavi.

L.P.

\section{Seabed mining for India \\ New Delhi}

Following the formal acceptance and registration of its claim by the executive body of the preparatory commission of the International Seabed Authority in New York last month. India is now entitled to mine manganese nodules from an area of $150,000 \mathrm{~km}^{2}$ of the seabed of the Indian Ocean, about $3,000 \mathrm{~km}$ south of the tip of the Indian land mass.

K.S.J.

\section{RAWMAC reservations \\ London}

THE British government's independent Radioactive Waste Management Advisory Committee has again expressed reservations about the ability of existing facilities to cope with increasing amounts of low-level nuclear waste. The committee's new chairman, Professor John Knill, says there is a risk that the $\mathbf{3 0 0}$-acre low-level dump at Drigg, in Cumbria, "will be put under pressure" following the government's decision last May to abandon plans to find a new low-level waste site, which would have been operating by the early 1990s (see Nature 327, 93; 1987). Furthermore, estimates for the total volume of waste expected during the next 25 years have been revised upwards by 30 per cent to $500,000 \mathrm{~m}^{3}$, mainly due to the removal of contaminated surface soil at British Nuclear Fuel Ltd's new thermal oxide reprocessing plant, under construction at Sellafield.

Knill says the abandonment of the shallow-site investigations have resulted in the loss of geological data that could have been of value for investigations into a deepdisposal site for low- and intermediatelevel waste. 